\title{
Organizational Culture and Civil Service Performance in Nigeria: A Study of Akwa Ibom State Ministry of Education (2010-2021)
}

\author{
ANIETI, NSEOWO UDOFIA \\ Department of Political Science and Public Administration \\ University of Uyo, Uyo, Akwa Ibom State, Nigeria. \\ Email: anietiudofia@uniuyo.edu.ng \\ Tel: 08060853959
}

EBONG, ITORO BASSSEY

Department of Political Science and Public Administration University of Uyo, Uyo, Akwa Ibom State.

Email: ebongitoro951@gmail.com

Tel: 08131378061

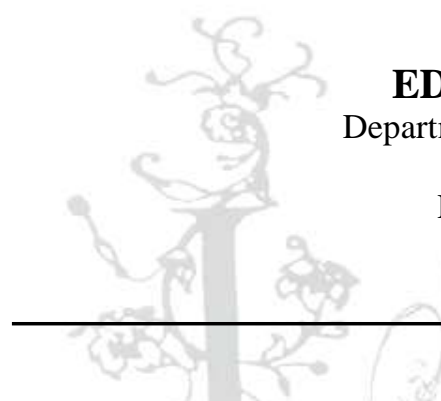

EDEMIDIONG, EDEM EDEMEKONG

Department of Political Science and Public Administration

University of Uyo, Uyo, Akwa Ibom State.

Email: edemedemekongedemidi@gmail.com

Tel: 08065810428

Civil service unlike any other public organizations is glued by norms and culture that regulate workers behavior and attitudes toward efficiency. These culture and principles serve as mode of operation upon which duties, offices are bound. Hence, employed are expected to adhere to the established norms of organization for efficiency service deliver. However, based on the above highlight, the civil service in Nigeria cannot be said to have up to its expectation of delivery qualify services to the people that will further help the government deliver on its mandate. This poor performance could be traced to low morale and weak morale which makes workers to neglect the culture and principles of the Civil Service which is anchored on meritocracy, impartiality, anonymity etc. The civil service in Nigeria still reels in politicization, merit sacrificed for quota-based recruitment/promotion, fraudulent staff claims, abuse of office/position, bribery and corruption, absenteeism, lateness, lack of organizational commitment, insubordination, aggrandizement etc. The paper adopted survey and descriptive research method and data were drawn from both primary and secondary sources. It was found out that the civil service is currently bedeviled with poor organizational culture and practices such from lateness, insubordination, lack of commitment to work, undue interference from the political office holders and other myriad of systemic problems. Based on the findings, the study concluded with some policy recommendations that civil service principles and culture should be highly adhered to by the civil servants which will in turn usher in the most needed productivity in the service.

Keywords: Civil service, Culture, Organizational Culture, and Performance. 


\section{Introduction}

Organizations are designed to achieve goals and objectives by bringing people together on a shared platform and inspiring them to succeed. Individuals in the workplace have a shared style of doing things to reach specified goals. Individuals working together in an organisation, according to Schein (1992), must have a pattern of mutual assumptions that is cultivated as the organisation solves its issues of outward adaptation and internal assimilation. This fundamental premise should hold up well enough to be taught to new members as the proper way to view, think, and feel about those issues (Boyle and Donnel, 2008).

Every nation's civil service is critical to its long-term growth. The government implements policies, programmes, and services through its Ministries, Departments, and Agencies (MDAs) to aid galvanise growth at all levels, foster economic advancement, and enhance trust and connection between state management and the people (Imhonopi and Urim, 2013). As a result, discussing government policies and programmes is pointless if there is no assurance that, once developed, such policies and programmes will be executed effectively and efficiently (Idang, 1988).

According to Idakwoji (2011), academics of public administration have long recognised the logic and validity of the thesis that civil service is the foundation of governmental management. The efforts of such experts have led to the realisation that any nation's socioeconomic growth will plummet without a lively and active civil service. However, they can only do this to their full potential if they adhere to an active organisational culture and ideals.

Organizational culture, on the other hand, may be an abstraction, yet it has a significant impact on how companies think and operate. Working culture, on the other hand, differs from one civilization to the next, as well as from one organisation to the next (Suleiman, 2013). Workplace culture, according to Boyle and Donnel (2008), has an influence on organisational productivity because it impacts worker performance. Unlike any other government agency, the Nigerian Civil Service is governed by a culture and set of practises that govern employee behaviour and attitude toward work. According to Akpala (1993), the civil service's cultural practises and norms make it one of the most admirable professions since they serve as the government's engine room, holding the key to its success and capacity to administer the state's business effectively and wisely.

On the contrary, due to weak cultural practises, the performance of the Nigerian public service has been riddled with inconsistencies (Adeyemo and Salami, 2008). One of the most serious issues confronting Africa's newly developing nations, particularly Nigeria, is the civil service's failure to implement government programmes and provide different social services in accordance with civil service norms and culture.

Ukpong (2019) attributes Nigerian workers' low productivity to a number of issues, including a failure to follow essential organisational culture and practises. In Akwa Ibom State, indiscipline, red tape, secrecy, insensitivity, rigidity, apathy, incompetence, lack of creative imagination, favouritism, lateness, loitering, truancy, rudeness, laziness, high handedness, malingering, and official log rolling have all contributed to the state civil service's inefficiency. As a result, it is critical for the government to pay close attention to civil service culture (Donnell and Boyle 2008).

All civil employees should embrace the required Code of Ethics in order to continue moving the Civil Service in the correct path. The term "ethics" refers to a culture that is founded on accepted ideals and principles. In the execution of his responsibilities, a civil servant should demonstrate professional discipline, dignity, honesty, equity, impartiality, justice, public-spiritedness, and civility, particularly in his dealings with superiors, colleagues, and subordinates, as well as the general public. This research uses the civil service of Akwa Ibom State as a case study to explore how civil service culture impacts organisational performance. 


\section{Statement of the Problem}

Nigeria is not alone in its quest to improve the lives of its citizens via good governance and a responsible public service for effective and efficient service delivery. A professional, competent, and result-oriented Civil Service with the impetus to effectively discharge its catalytic role of facilitating the successful conception, planning, execution, and monitoring of the government's policies, projects, and programmes is a critical success factor in realising the government's lofty objectives. Only such a civil service can be useful and indispensable to the political elite.

Due to non-adherence to civil service culture and procedures, the civil service in Nigeria, notably in Akwa Ibom State, has essentially disintegrated with low and weak morale, efficiency has vanished, competence has been abandoned, and merit has been abandoned. Politicization, quota-based recruitment/promotion, false employee claims, misuse of office/position, bribery and corruption, absenteeism, lateness, lack of organisational commitment/citizenship, laziness, insubordination, aggrandisement, and other issues still plague the public service.

In Akwa Ibom State, arriving late for work has become a civil service culture and practise. The majority of government workers in various ministries have developed a habit and culture of arriving late to their job stations. Even when they report to work, most public officials prefer to wander around and talk with their coworkers and acquaintances. This has a detrimental impact on organisational productivity since time that should be spent on work duties is diverted to nonprofit-able connections, reducing organisational efficiency.

As a result, in Akwa Ibom State, a lack of dedication to assigned occupations and duties poses a significant barrier to civil service efficiency and production. Some public workers feel that government work is the responsibility of no one. They think that government labour is performed in the service of some vague and indefinable power, whose job is never completed or completed, but rather continues indefinitely. As a result, their job dedication isn't always exact and efficient. This has a detrimental impact on government efficiency and productivity.

It's distressing to learn that the state civil service is suffering from a performance problem and a conundrum, owing in large part to the current civil service climate, bad work culture, and the lack of a performance management agenda. The general environment created by the aforementioned factors has the potential to stifle the much-desired process of establishing and maintaining a result-oriented management of a team of competent, efficient, goal-driven, proactive, and value-adding human resources for improved organisational or institutional performance. As a result, many Nigerian Civil servants are known to participate in extracurricular activities that give them a real sense of success but leave them too exhausted or with inadequate time to do their jobs well. This, in turn, has an impact on employee performance and organisational productivity. The research attempted to address the following questions based on the concerns raised:

i. To what degree has tardiness in the Akwa Ibom State Civil service hampered organisational productivity?

ii. How has a lack of dedication impacted the Akwa Ibom State Civil service efficiency.

\section{Objectives of the Study}

1. To examine the extent to which lateness to work affects organizational productivity in Akwa Ibom State civil service.

2. To investigate the extent to which lack of commitment affects staff efficiency in Akwa Ibom State civil service 
3. To proffer solutions that will help in successful implementation of organizational culture and norms in Akwa Ibom State civil service.

\section{Hypothesis of the Study}

i. Lateness to work tends to affect organizational productivity in Akwa Ibom state civil service

ii. Lack of Commitment among workers is likely to affect staff efficiency in Akwa Ibom State civil service

\section{Conceptual Clarification}

\section{Concept of Organizational Culture}

Culture is described as a whole way of life within a given civilization. Similarly, culture serves as the "social glue" and fosters a "we-feeling," counteracting the inevitable processes of divergence that occur in organisational life. Organizational culture gives a common set of meanings that is the basis for communication and mutual understanding. If these tasks are not achieved in an acceptable fashion, culture may considerably impair the effectiveness of an organisation (Armstrong, 2012).

Culture as a notion has had a long and troubled history. It has been used by anthropologists to describe to the practises and rituals that civilizations establish throughout the course of their history. In the last several decades, term has been used by some scholars and managers to refer to the environment and practises that firms create around their treatment of people, or to the professed ideals and credo of an organisation (Schein, 2004).

Cameron and Quinn (2011) emphasise that there are numerous layers of culture that impact individual and organisation behaviour. At the widest level, there are global cultures such as that of a universal religion or the culture of a region, for example, Asia or Europe, or national distinctions found between the people of specific nations. At a less general level, there are subgroups that are occupation or industry-based, for example, police culture or those relating to the high-tech industry. Lastly, there are cultures inside companies.

Organizational culture may be characterised in terms of values, norms, artefacts and management/leadership style. Organizational culture (also known as corporate culture) is the pattern of values, conventions, beliefs, attitudes, and assumptions that may not have been stated yet affect the manner in which people in companies behave and things get done (Armstrong, 2012). This concept highlights that organisational culture is concerned with the subjective component of what goes on in companies. It refers to abstractions such as ideals and conventions that pervade the whole or portion of a business.

Charles Handy (1981) found that in each organisation, public or private, there are fundamental ideas about how labour should be structured, how people should be paid, and how people should be managed. Hence, if there is an acceptable and successful culture, it would be beneficial to take efforts to promote or strengthen it. On the other side, if the culture is unsuitable, steps should be made to establish what needs to be changed and to design and implement strategies for change (Armstrong, 2012). Hence, civil service culture is contained in the multiplicity of rules and regulations regulating the procurement procedures that are required to be adhered to.

\section{The Concept of Civil Service}

The phrase "civil service" is generally used when referring to the body of men and women hired in a civil capacity on a nonpolitical career basis by the Federal and State governments, principally to render and truthfully give effect to their decisions and execution (Ipinlaiye, 2001). It is an institution made up of a 
body of individuals engaged and paid by the government to implement the laws, plans, and policies of the government (Akpomuovire, 2007).

The civil service is the machinery of government that aids in creating and implementing government policies (Afolabi, 2011). Specifically, the civil service is made up of workers in government ministries, parastatals, and other agencies that are further expected to provide continuity in governance, and to serve as a repository of knowledge and experience of the practises and procedures of governance and to protect the public interest (National Political Reform Conference, 2005).

The civil service, which is made up of the workers of the government, is an essential tool through which the government implements its policies and projects. It is via its instrumentality that government policies are turned into services for the people. They are those accountable for the operation of the government via the execution of government policy (Afolabi, 2011).

In the opinion of Ezeani (2006), the civil service is the administrative machinery within which the job of government is carried out. It is a one-of-a-kind entity that is ideally positioned to play a key role in the effective running of government. Per Anazodo et al. (2012), the Civil Service is the administrative machinery that has a vital place in the political system. It is the nerve hub of governmental management. Thus, it is an essential conditioning element or determinant of the success or failure of any government's development programme or plan.

The 1999 Constitution of the Federal Republic of Nigeria, as amended, defines civil service as a service of the Federation in a civil capacity as staff of the Office of the President, the Vice-President, a ministry or department of the Government of the Federation assigned with the responsibility for any business of the Government of the Federation.

Anazodo (2009) contends that the civil service in Nigeria comprises personnel in the different ministries or departments, separate from those who hold political posts. The major tasks of the civil service are primarily to assist create and implement the policies of the government and to offer associated services to the people. Practically, therefore, the entire organisations which constitute the government's mechanism for executing policies and programmes and delivering services which adequately meet the needs of the citizenry are called the civil service, whose fundamental roles are to serve the public, the nation, and the community, and also to effectively promote the common good. The principles in the execution of these commendable tasks include accountability, responsiveness, politeness, objectivity, impartiality and preserving the public confidence at all levels.

Continuing with the aforementioned perspective, Imuetinyan (2004) argued that civil servants are those public servants who are direct employees of both the federal and state governments, other than the police, armed forces members, and teachers. The objectives of government are generally embodied in its purposes and goals, while the civil service (or the bureaucracy) supplies the people needed to realise the vision and mission of government as well as implement programmes and initiatives.

A civil servant is required to assist in formulating and implementing the policies approved by Government and whatever his personal or private opinions or attitudes may be. This does not mean that a civil servant should undertake illegal action; if so directed, he should invite attention immediately to the legal position or requirement and advise on the proper action to take. He has the duty also to advise on the implications of a policy or action. However, elected members come and go but the civil service remains. When a Civil Servant relinquishes his office for whatever reason, his place is taken by another person who similarly enjoys security of employment. 


\section{Functions of the Civil Service}

Essentially the functions of the Civil Service are to:

i. Contribute to translating the dreams and visions of the political/ruling class into concrete reality through the formulation of far-sighted policies and programmes and executing same loyally, conscientiously and effectively;

ii. Provide continuity between administrations;

iii. Serve as a unifying factor by bringing together people from all parts of the federation, providing effective and adequate social services;

iv. Advise government on the full implications of various policy options open to it;

v. Execute government policy loyally;

vi. Protect public interest, as custodian of public conscience;

vii. Manage government data and information system effectively and efficiently so as to facilitate availability of data for government decision making;

viii. Operate an open, humane and sensitive system which respects the rule of law;

ix. Operate a personnel management system that ensures high professionalism, significant specialization, excellent motivation and high morale; and

x. Ensure prompt, effective and satisfying service delivery.

\section{Concept of Performance}

In the social sciences, the term "performance" has been defined in a variety of ways by researchers and writers. As a result, there is no universally recognised definition for the notion. As a result, it has been seen from several perspectives. For example, in terms of process, performance denotes the transformation of inputs into outputs with the goal of achieving a certain result.

According to Bernadin (2010), performance is the result of labour since it has the strongest relationship to an organization's strategic goals, customer happiness, and economic contribution. When performance is defined as encompassing both behaviour and consequences, however, it becomes more complete. Brumbach (2010) expresses this effectively when he states that "performance" encompasses both behaviours and outcomes. Performance is transformed from abstraction to action through the performer's actions. Behaviours are not only instruments for results; they are also outcomes in and of themselves, the consequence of mental and physical effort put to activities, and may be assessed independently of results.

Employee performance, according to Muchinsky (2003), is a collection of behaviours that may be analysed, gauged, and assessed in terms of individual achievement. It is a measurable and quantifiable accomplishment. According to Bhatia and Jain (2012), performance may be measured using a combination of quality, quantity, time, and cost. Originally, worker performance refers to what a worker does or does not do. According to scholars (Mathis \& Jackson 2009), performance is linked to amount and quality of production, productivity over time, and the appearance of completed and efficacy of job completed.

From the standpoint of the organisation, employee performance is generally defined as the extent to which a single person affects the organization's capacity to achieve its goals. Aydogdu and Asikgil (2011) believed that work attendance, performance-related responsibilities, and organisational behaviour could all be used to evaluate various aspects of performance. Employee performance in the Nigerian civil service might be defined as the act of civil employees doing their responsibilities in accordance with the civil service's guidelines for efficient service delivery.

According to Ejiofor (1984), worker performance (WP) is a result of several linked and interrelated factors. Organizational Performance (OP) is determined by three key variables: the person working in the organisation $(\mathrm{W})$, the organisation itself $(\mathrm{O})$, and the environment in which the organisation works $(\mathrm{E})$. As 
a result, $\mathrm{OP}=\mathrm{f}(\mathrm{W}, \mathrm{O}, \mathrm{E})$. Ejiofor (1984) further on this by claiming that each of these three essential variables is a result of other elements. Worker performance (WP) is, for example, a result of his ability (A), motivation (M), and integrity (I) (I). As a result, $\mathrm{WP}=\mathrm{f}(\mathrm{A}, \mathrm{M}, \mathrm{I})$.

Similarly, Ejiofor (1984) found that a worker's ability (AW) is a function of his genetics (g), his perceived need $(\mathrm{N})$, and the environment $(\mathrm{E})$. He concluded that, despite many attempts to improve the public sector in Nigeria since independence, such efforts have not generated desired outcomes, in part because reformers frequently presume a unilinear relationship between organisational incentives and worker performance. Indeed, as the author points out, a cheerful worker in Nigeria is not always an unmotivated one. The outcome is usually unsatisfactory when only one variable (i.e., the incentive system) is recognised and modified while the remainder is mostly unaffected. The civil service is, in theory, an administrative structure. It comprises all such outfits, people, structures, tools, tasks or duties, processes, and goals or objectives, according to Michels (1952).

The civil service, as a structured and bureaucratized institution, is affected by Weber's (1942) distinctive stereotypes, which include, among others, division of labour, impersonality, permanence, professionalism, impartiality, hierarchy, and meritocracy. Furthermore, according to Selznick (1952), the public service is continually shaped by factors unrelated to the system's logically organised architecture and declared aims. The operations and goals of the service become more dynamic as a result of this. Often, politicians and system designers are unable to examine all of the repercussions of their decisions due to their desire to provide for and achieve defined goals. These additional impacts occur as unintended outcomes and have an impact on the setup. It is impossible to say that this does not apply to Nigeria's civil service.

This logic was used by Selznick (1952) to support his claim that "all formal organisations are shaped by forces tangential to their rationally ordered architecture and professed purposes." This is likewise true for the Nigerian Civil Service. There is also an assumption that unwanted or unforeseen outcomes or consequences are the result of sociologically defined factors. This premise is based on the notion that, like any other organisation, the civil service's human tools of action arrive in the system moulded in unique but systematic ways. The character of Nigerian public servants is shaped by their aspirations and training, as well as societal ideals, class interests, ethnic beliefs, and other factors. If the service, in its different components, tries to mobilise its human and technological resources as tools to achieve its goals, and certain persons inside the system reject being viewed as such, this explains the service's poor performance.

Their actions are a result of their pre-service anxieties. There are usually certain informal structures inside the organisational system that represent the simultaneous activities of people and subgroups. They strive to influence or try to influence policies and policy implementation to their benefit in order to control the conditions of their existence and defend their individual class, etc. interests. In Nigeria, similar attempts have been known to succeed less frequently. They reroute policy execution to serve unintended goals. Human structures, as Selznick (1952) puts it, always mediate social activity, not just by generating new centres of need and power, but also by interposing themselves between the actor-institution and themselves. Inadvertently, they present the system with imperatives that may need adaptation measures not anticipated by the interposing centres of authority, resulting in a deviation of the original aims.

\section{Review of General Literature}

The Nigerian civil service, like any other civil service, is a well-organized group of permanent officials, ministries, and government agencies tasked with carrying out government policies and programmes according to established rules and procedures (Udokang, 2016). The civil service is a branch of the executive branch of government tasked for carrying out the government's laws, policies, and programmes. According to Udokang (2016), the civil service, in addition to being the arm of the nation's political system tasked with the overall administration of government, converts government plans and programmes into concrete services or realities for citizens. According to Obi (2005), the civil service of the Federation is 
defined as service of the federation in a civil capacity as staff of the president's office, vice-office, president's a ministry or department of the federation's government, or any other position within the federation's government assigned with responsibility for any business of the federation's government.

According to a survey of the literature on culture, the majority of authors think that organisations can only be completely understood through understanding their culture. As Schein (2004) points out, once we learn to see the world through cultural lenses, all kinds of things start to make sense - why some departments seem more interested in fighting with each other than getting the job done, why communication problems and misunderstandings that should not happen between reasonable people do, and why, despite being told in detail why something different must be done, people continue to act as if they haven't heard. Donnell and Boyle (2008; Donnell and Boyle, 2008).

Furthermore, organisational culture is increasingly being recognised as a critical component in business success. Most organisations are reconsidering what they do and how they may best achieve their goals and objectives in the face of a fast changing external environment. Reflecting on the sort of culture required to achieve these aims and objectives is a part of this process (Schein, 2004). Organizational culture, in particular, appears to play a crucial role in motivating and maximising the value of intellectual assets, particularly human capital,' as Baker (2002:1) points out.

According to Cameron and Quinn (2011), the most crucial competitive advantage of successful businesses is their organisational culture. They mention Coca-Cola, Disney, GE, Intel, McDonald's, Microsoft, and Toyota as examples of companies that have established distinct cultures with which its employees can easily identify.

Organizational culture develops through time as most businesses face and overcome barriers and difficulties in their environment, or it may be intentionally established by management teams that want to improve the company's performance in a methodical approach. While these characteristics are crucial, many very successful businesses have harnessed the strength that emerges from and lives in a distinctive corporate culture (Cameron and Quinn, 2011).

As a result, a good culture helps businesses to achieve their stated goals and objectives (Cornish and Gilbert, 2005). Moreover, numerous research have been done from various viewpoints on the influence of culture on worker performance. Nonetheless, there is no statistical evidence that organisational culture has a direct impact on employee performance and organisational productivity, whether in the public or private sector (Abdullah \& Francis 2012).

As a result, there are several tasks that must be completed in order to improve the service's overall performance. The majority of Nigerians, according to the Political Bureau's study (1987), believed that the collapse of the first and second republics was due to the operators, not the system. Due to bad cultural practices and conduct, this may also be stated about the civil service.

\section{History of Nigerian Civil Service}

As previously stated, the Nigerian Civil Service is a product of colonial legacy. It is made up of Ministries and Departments with Extra-Ministerial Functions. It experienced a number of structural changes throughout the colonial period in order to make it more practical and appropriate to the reality of Nigeria's surroundings. Some major measures taken to reorganise the Nigerian Civil Service include the Harragin Commission (1946), the Gorsuch Commission (1955), and the Nigerianization of the Civil Service Policy (Oshionebo, 1992).

The federal, state, and municipal civil services were essentially weak by 1999 , and were largely viewed as political, corrupt, demoralised, and ineffective. The Nigerian public service has morphed from a 
manageable, compact, focused, trained, skilled, and high-motivated body into an over-bloated, lopsided, illequipped, poorly compensated, merciless organisation, devoid of initiative, and plagued with morale, arbitrariness, and corruption (Federal Government of Nigeria, 2008).

The trend of bureaucratic modernisation continued after the country gained independence in 1960. A number of commissions were established to evaluate public-sector salaries, pay, and other terms and conditions of employment. The Morgan Commission (1963) was the first of these commissions, and it looked at the pay, salaries, and working conditions of junior government workers in the federation of private companies. The panel established a national minimum wage based on regional criteria. The Elwood Grading Team was established by the government to investigate anomalies in the grading and other circumstances of all posts in the federation's public services, with the goal of finding acceptable gradings and creating consistency in the wages of officers doing identical responsibilities.

Although the Adebo Commission (1970-71) looked into current pay and salaries, it also recommended that a Public Service Review Commission be established to look into the civil employment's structure, organisation, management, terms of service, and training arrangements. The Udoji Commission (1972-74) was one of the recommendations (Osionebo,1992). However, these changes had no major influence on the civil service's performance. This rationale may have influenced the 1988 announcement of yet another change. This conclusion is based on a statement made at the then-Secretary of the Federal Government's inaugural speech, in which he confessed that the civil service is now a wounded institution,... one in which morale has plummeted, and in which excessive bureaucracy and interminable delays have become the norm. The institution appears to be resistant to change and has become a frequent target of public criticism (FGN, 2008).

This prompted a new, more drastic reform in 1988, as well as a review in 1994, both led by Dotun Philips and Allison Ayida. The Musa Ahmed reforms were launched in 2003. Most of the above-mentioned review commissions, according to Anazado (2008), concentrated on the assessment of workers' working conditions, particularly pay and earnings. Only the Udoji Commission, the Dotun Philips Review Panel, the Allison Ayida Commission, and the Musa Ahmed reviews looked into the operations and structure of the civil service and recommended major reforms aimed at reducing corruption, mediocrity, inefficiency, ritualism, red-tapism, and other issues that plague the civil service. The reform efforts focused on using information and communication technology to modernise core operations, increasing public servant accountability to citizens, reducing waste and inefficiency, consolidating various allowances and fringe benefits into salaries, computerising payrolls, and introducing a contributory pension scheme (Olaopa, 2010). All of this has had little impact on the civil service's performance.

Adedeji (1970) outlined some of the key difficulties that afflicted the Nigerian Civil Service and dramatically impacted its performance some decades ago. These included issues arising from the structure and organisation of service recruitment into the administrative class without taking administrative experience into account, resulting in a lack of professionalism, an overreliance on seniority rather than demonstrated efficiency, and a lack of progressive wage and salary structures to align with the current economic reality.

Lack of inter-sectoral mobility of personnel was also recognised as a concern. From the private sector to universities to the civil service, examples include corruption and tribalism, a lack of service control that could have improved constant performance measurement, a lack of quality, dedicated, and self-disciplined leadership, and a lack of comprehensive, forward-looking staff development and training programmes. The majority of the Nigerian Civil Service's reforms and evaluations were aimed at resolving these issues.

Despite all of the evaluations and efforts aimed at making the civil service more goal-oriented, Arowolo (2012) found that the Nigerian Civil Service is marked by poor performance and an inability to transform government plans and programmes into reality. Despite all of the procedures put in place to address the 
Nigerian Civil Service's performance failure, the problem has resisted all attempts to address it. Wamakko (2013: 1) criticised the dismal performance of Nigeria's civil service. The service is marked by indiscipline, inefficiency, ineffectiveness, lack of dedication to service, disloyalty, partisanship, lack of ethics, contempt for processes, disrespect for established authority, poor work attitudes, lack of dedication, and disregard for norms and regulations in practically every facet. Hence, something had to be done, and it had to be done quickly.

While admitting that the Nigerian Civil Service is big and has contributed to the nation's growth and progress, Awosilia (2014) believes that most components of the developmental process, particularly technology, are not sufficiently supplied. According to the author, this has resulted in the Nigerian Civil Service being one of the slowest to adopt technological advances. The service has been characterised by corruption, excellent manners, nepotism, and formality, resulting in inefficiency, low performance, and productivity (Anazodo, Okoye, and Chukwumeka, 2012).

The comment holds true today as well as it did before, since no significant changes have been observed despite all service modifications. There is still a lot of clamour for the civil service to be restructured for maximum performance. Ejionye (1984), in support of this viewpoint, stated:

Today's Nigerian worker is slacker and sluggish. He avoids labour and responsibilities, yet he adores money, riches, and all of life's pleasures. The Nigerian worker is materialistic, pleasure-seeking, and egotistical, and he or she desires to get wealthy quickly. He values social status and desires to be seen, acknowledged, and treated with respect as the "oga," the guy in control of things. Less work, longer breaks, excuses, duty certificates, permitted casual absences, upcoming public holidays, and imminent industrial action were the top concerns of most paid employees in Nigeria. All of this is on top of regular pay increases, enticing allowances, fast promotions, false claims, abundant perks, and bouncing bonuses. Such attitudes still exist among Nigerian employees, and they are a hindrance to achieving peak performance.

\section{The Core Culture and Principles of Civil Service}

The core principles of the Civil Service in Nigeria are:

\section{i. Stewardship}

They are answerable to Nigerians and the current government as public workers. As a result, government officials perform their stewardship duty by making effective use of time and managing the material, financial, and human resources given to them by the nation for the common benefit. They must offer citizens with timely, accessible, cost-effective, and high-quality service, as well as fulfil their diverse requirements and expectations and diligently implement the government's policies and programmes.

\section{ii. Professionalism}

Civil servants must continue to uphold the highest professional standards in their work as part of their commitment to excellence. As a result, they will work to foster the flow of ideas, information, and enterprise in the civil service, both individually and collectively, by continually upgrading their skills and competences through individual self-development and utilising the service's training possibilities. They must avoid all types of unprofessional and unethical behaviour. Civil servants should constantly strive to preserve candour towards political office holders and other government authorities via objectivity and impartiality in advice as nonpartisan state employees with professional devotion to the government of the day. 


\section{iii. Political Neutrality and Duty of Confidentiality}

This concept states that public employees should not utilise their positions, roles, or responsibilities for political or partisan reasons that might harm the civil service's interests. Even after he leaves office, they shall preserve the secrecy of official information to which he has access as a result of his professional activity, unless the law, lawful authority, or the interest of justice dictates otherwise. They should not try to influence or modify the policies, choices, or actions that the administration has decided to define, adopt, or execute based on his political affiliation or ideological convictions.

\section{iv. Integrity and Moral Rectitude}

Any action that is inconsistent with ethics and morals, such as misuse of public funds, favouritism, nepotism, discrimination, influence-peddling, or administrative indiscretion, should be avoided by civil officials. They shall not seek, accept, demand, or receive any cash, gift, or other in-kind benefit in exchange for executing or abstaining from performing tasks or responsibilities, whether directly or indirectly. It is unethical for a government worker to provide gifts or other benefits that could influence the judgement or choices of another individual in his or his family's or friends' favour. Under no circumstances may a government official misuse public property or compel subordinates to do actions that are not within the scope of their duties or mandate.

\section{v. Discipline}

Civil servants need to be well-behaved. Rules and regulations must be followed, and the service's interests must come first. Senior officials should establish a code of behaviour that they can and should adhere to. Those who aspire to lead others should keep in mind that effective leadership necessitates exceptional character, hard effort, and honesty. One of the requirements for advancement is good behaviour. Junior officials should be well-versed in government regulations and norms about proper conduct. They must learn to respect and follow legitimate authority.

\section{vi. Loyalty}

Civil employees should be loyal to the government that has entrusted them with their duties. No officer or employee should believe that he or she is entitled to a salary or compensation unless he or she provides appropriate service in return. The government is under no duty to keep ineffective or disloyal employees.

\section{vii. Honesty}

Civil officials should be truthful in their work and interactions with the public. They should understand that they are compensated for the work they do. This implies they should be diligent while on duty and should not demand or accept anything in cash or in kind from anybody while doing their responsibilities.

\section{viii. Courage}

One of the most valuable qualities of the top government employees is courage. This trait can be displayed in a variety of ways. It might be demonstrated by working hard in a demanding job, because there is no need to be afraid of hard labour. Civil workers should develop the fortitude to put in long hours. They should not be afraid to take on a large number of responsibilities. Another form of bravery is doing what is ethically correct even if one does not stand to benefit personally from doing so. They should perform the correct thing in their daily routines, especially if it would improve the service's and country's reputations. They must fight temptation from all sides at all times. When a superior authority's approval is required, they must be gracious in obtaining it. 


\section{Organizational Culture and Workers Performance: The Nexus}

The notion that having the appropriate kind of culture has a beneficial influence on organisation performance has long fueled interest in organisational culture. Many firms were included in Peters and Waterman's In Search of Excellence in the early 1980s that scored poorly on well-known essential success characteristics such barriers to entry, capacity to develop economies of scale, or product nonsubstitutability. Nonetheless, due to their organisational culture, these firms were supposedly quite successful at the time. Furthermore, there is significant anecdotal evidence that inability to transform the organisational culture is the major cause of many change efforts in companies, such as business process reengineering or comprehensive quality management (Baker, 2002).

The method was viewed as a technique or programme of change, not as a fundamental transformation in the organization's direction, values, and culture, and without this, there is little prospect of permanent improvement in organisational performance,' Cameron and Quinn (2011:12) argue. Indeed, unsuccessful attempts to change frequently result in cynicism, frustration, a loss of confidence, and a decline in morale among many workers, leaving organisations in a position where they may be worse off than if the change strategy had never been undertaken in the first place.

A functioning organisational culture promotes organisational performance in a variety of ways, according to the Victorian Public Service Commission (VPSC, 2015:6): Because individuals in a functional culture share conventions, beliefs, and methods of engaging, the organisation is better able to handle risk, uncertainty, and ambiguity. This establishes the ground rules and gives employees with'mental models' to assist them deal with uncertainty and anxiety associated with change.Because of how employees feel about their workplaces, the organisation has a more good reputation, which will show in how they speak about it. The organisation provides better service because its employees are more motivated and engaged, and they are more able to address challenges.

The report's study also outlines some of the challenges that might occur when organisational cultures aren't working. A values conflict can occur when employees do not share the same values as the organisation or when what the employees value differs from what the organisation requires. 'A values mismatch emerges most often as disengagement and a lack of motivation,' according to the VPSC study (2015:6). 'Work to rule' or 'clock monitoring' replaces discretionary effort. When more vocal individuals are involved, or when there is power in numbers, a conflict might appear as agitated behaviour, factionalism, or the formation of silos and countercultures, all of which actively work against the organization's best interests. Productivity and service quality will inevitably decline.

The relationship between employees and company culture has long been recognised. According to Taylor (2014), there is a substantial link between organisational culture and performance. As a result, both academics and practitioners have highlighted that many public organisations, including the civil service, fail owing to a lack of commitment to organisational culture and norms.

\section{Challenges Facing Civil Service Efficiency in Akwa Ibom State}

\section{i. Lateness to Work}

Lateness to work is one of the issues that plagues public service efficiency. In Akwa Ibom State, this has established a civil service culture and practice. The majority of government workers in various ministries have developed the practice and culture of arriving late to their job stations. Most public workers do not stay on duty even when they report to work. They like to go for walks with the purpose of chatting with their coworkers and pals. This has a detrimental impact on organisational productivity since time that should be spent on work duties is diverted to non-profitable relationships, which has the potential to reduce organisational efficiency. 


\section{ii. Lack of commitment}

In Akwa Ibom State, a lack of dedication to assigned responsibilities and duties also poses a significant barrier to civil service efficiency and production. Some public workers feel that government work is the responsibility of everyone. They think that government activity is carried out in the service of some vague and indefinable power, whose job is never completed or completed, but rather continues indefinitely. As a result, their job dedication is not always exact and efficient. This has a detrimental impact on the efficiency and productivity of the civil service.

\section{iii. Envy/Jealousy among Staff}

In their employment, some public workers are green with envy. They are envious of or jealous of their coworkers. Those who are inefficient and non-performing envy those who are industrious and dedicated. The sluggish ones moan when their managers use the efficient ones to do critical assignments in order to achieve objectives and deadlines. Unserious public servants in Akwa Ibom State maintain stacks of unprocessed paperwork and wait until 4 p.m., when work hours stop. They are abrasive, easily irritated, and confrontational, making excuses and blaming others for their misfortunes. As a result, a shift in mindset and a willingness to learn the profession with humility would be a good solution.

\section{iv. Bribery and Corruption}

Civil officials in Akwa Ibom state have a reputation for being corrupt, indulging in questionable lifestyles while on the job. Before handling people's problems, some public employees demand and expect satisfaction. When such demands are put on fellow public workers and colleagues, it is very humiliating (Afahanam, 2010). Some go so far as to offer and accept bribes, while others engage in deceptive methods. It can be perplexing to find junior government servants with no other employment owning a home, a fleet of vehicles, and leading a flashy lifestyle, while senior colleagues still walk to and from work or rely on public transit. Unless proven differently, the source of money becomes suspect in this scenario. As a result, the service's integrity suffers because it is not a basic value.

\section{v. Using official working hour for personal businesses}

It is common knowledge in Nigeria, particularly in Akwa Ibom State, that many offices, particularly technical departments, officials report for duty in the morning and then disappear to pursue their private businesses a few minutes later, leaving a note in the office stating that they have gone on "inspection." Some officers, particularly women, leave the office for "school runs" to pick up their children and do not return until the next day; some teachers have been caught abandoning their pupils/students to buy and sell in the markets; and some workers do not bother to bring their articles and wares to the office to sell, even displaying or showcasing them on tables meant for files. Planting, weeding, and harvesting during business hours is acceptable to those who have farms near their offices. As a result, government officials should be conscientious and truthful in their use of official time.

\section{Vi. Political interference and favouritism}

Even when a more efficient workforce is available, certain officers are granted excessive and unjust benefits by their superiors inside the military. When employee A commits a crime, no one notices, but when employee B is implicated, a red flag is raised. This may or may not be the case depending on one's connection with his or her employer.

Favoritism can be based on a variety of factors, including gender, ethnicity, religious preference, and shared membership in a club or group. Favoritism is inefficient and should be avoided in the workplace. Favoritism is always a criterion for recruitment and promotion of employees from one post to another in 
Akwa Ibom State during recruitment, promotion, and appointment of persons into service. This has a detrimental impact on organisational productivity and lowers employee morale since individuals who are due for advancement are not considered. Furthermore, these practises allow for the appointment and recruitment of mediocrity into service, resulting in even more inefficiency.

\section{vii. Gossip and Rumour}

Gossip is the casual discussion about other people's issues, whereas rumour is a storey that is disseminated via conversation but may not be true (Hornby, 2000). During official hours, officers may leave their offices to visit other offices to discuss unofficial matters. They also spread rumours that begin with "the people say" or "they say," or "have you heard, my sister?" As a result, while the core civil service was not renowned for spreading rumours, such practises have grown commonplace, resulting in organisational disputes among ministries and agencies.

\section{Theoretical Framework}

To provide this effort a scientific foundation, the study utilised normative theory as a theoretical framework. Normative theory was created in 1954 by Edward to describe the norms and ethics that govern organisations and organisations. The idea argues that for any organisation to flourish there must be a standard culture, values and norms that control their operations and human conduct within the company. Hence, work place culture has an influence on organisational productivity since it impacts workers' performance as a whole. Once organisational culture is not fully followed with, there is sure to be a shortfall and low production in the work environment. This will in turn influence organisational outputs and performance.

This theory is relevant to this study because the civil service has operational rules and regulations guiding the conduct of government business as regards service delivery. Unlike any other public institution, the Nigerian Civil Service is circumscribed by culture and practices which control workers' behaviour and attitudes towards work. According to Akpala (1993), the cultural practices and norms of the civil service make the profession one of the most admirable professions, as they serve as the engine room of government, which holds the key to its effectiveness and its ability to manage efficiently and judiciously the affairs of the state. On the contrary, the performance of the public service in Nigeria has been replete with varied inconsistencies due to weak cultural norms. The civil service in Nigeria has not lived up to the promise of providing skilled services. This bad performance might be attributed to inadequate morale, which causes personnel disregard the culture and values of the Civil Service, which are founded on meritocracy, impartiality, anonymity, etc. The civil service in Nigeria is typified by false employee claims, misuse of office/position, bribery and corruption, absenteeism, lateness, lack of organisational commitment/citizenship, laziness, insubordination, aggrandisement, etc. This emphasised problem in turn impacts their performance and efficiency, as most civil employees are not doing enough to aid the government in achieving its mandate to the population when compared with their counterparts internationally.

\section{Research Methodology}

The study adopted survey and descriptive research design. Data for the study was collected with the aid of qualitative and quantitative research techniques. The quantitative method here includes the use of instruments such as questionnaire, interviews, and focus group discussions. The questionnaire was divided into two segments. The first segment introduced the researcher to the respondents and informed the respondents of the purpose of the research. It also gathered information on the bio-data of the respondents. The second segment took a structured format. The structured format contained 24 (items) questions for each respondent. The statements were posed in both open and closed-ended styles, whereby the 
respondents were not restricted to a set of predetermined answers to show their level of agreement or disagreement with the issues raised.

The study also relied on secondary sources of data. These comprised of published and unpublished text, journals, newspapers and magazines, conference and seminar papers, government bulletins, and existing literature on the subject matter. The internet was also used as a trustworthy source of information.

\section{Population and Sample Size}

The population of this research covers all personnel in the Akwa Ibom State Civil Service. For the purpose of clarity, five ministries were sampled for the study. These are the Ministry of Works, the Ministry of Finance, the Ministry of Agriculture, the Ministry of Health, and the Ministry of Education. One hundred and eighteen (118) respondents were randomly picked from each of the Ministries, bringing the total sample size to five hundred and ninety (590). Copies of questionnaire were provided to each of them, and their replies were incorporated in the final analysis.

Table 1: shows the population and sample size

\begin{tabular}{|llcc|}
\hline S/N & Population of study & $\begin{array}{c}\text { Population of } \\
\text { respondents }\end{array}$ & $\begin{array}{c}\text { Percentage } \\
\text { population }\end{array}$ \\
\hline \multirow{2}{*}{1} & Ministry of Finance Ministry of & 118 & $20 \%$ \\
2 & Agriculture & 118 & $20 \%$ \\
3 & Ministry of Health & 118 & $20 \%$ \\
4 & Ministry of Education & 118 & $20 \%$ \\
5 & Ministry of Works & 118 & $20 \%$ \\
& Total & 590 & $100 \%$ \\
\hline
\end{tabular}

The above table shows that a total of 590 population of respondents were sample for the study. However, sample for the study was purposively drawn from age $29-65$ and above.

\section{Sample and Sampling Technique}

A sample size of 590 respondents were drawn from the population of study, using simple random sampling, purposive and stratified sampling technique. This multi-stage sampling technique was adopted in order to reduce or minimize the degree of bias of the respondents during the distribution of questionnaire. The method was necessary because the researcher had to reach out to all the units/sections of the area where the respondents could be engaged for the purpose of eliciting information from them. Thus, out of 590 questionnaires distributed, only 570 were successfully completed and returned, same were used for the purpose of data analysis and to test hypothesis raised for the study.

\section{Procedure for Data Collection}

For this study, data were collected through the administration of questionnaires by the researcher. A total of five hundred and ninety (590) questionnaires were distributed out of which five hundred and seventy (570) were retrieved for analysis. Each of the ministries were given eighteen (118) copies of questionnaires. The rate of returns in each of the ministries was: Ministry of Works (113), Ministry of Health (116), Ministry of Finance (113), Ministry of Agriculture (114), and Ministry of Education (114). Bringing the total sample to 570 and same were used for the purpose of data analysis and to test hypothesis raised for the study. 


\section{Method of Data Analysis}

The data obtained was analyzed using quantitative and descriptive technique of data analysis to obtain logical deductions and sequential presentation of facts from the data obtained to give a clear picture of the problem. The Chi-square method of data analysis was used to analyze all the quantitative data and to test hypotheses at 0.05 alpha level to establishing the relationship between the independent and dependent variables, while the qualitative data was tested with the aid of descriptive method. Descriptive method of data analysis was premised largely on a Focus Group Discussion (FGD) approach using participants' opinion. However, two participants were selected from each of the five Ministries for the interview, bringing the total participants to ten (10) with the primary aim of eliciting information from the respondents for the purpose of evaluating hypotheses one and two.

\section{Testing of Hypotheses}

Table 2: Analysis of Responses from the Research Question I: lateness to work is likely to affect organizational productivity in Akwa Ibom State Civil Service

\begin{tabular}{|c|c|c|c|c|c|c|}
\hline $\mathbf{S} / \mathbf{N}$ & Statements & $\mathbf{S A}$ & $\mathbf{A}$ & D & S D & Total \\
\hline 1. & $\begin{array}{l}\text { There is a significant relationship between } \\
\text { lateness to work and poor job delivery among } \\
\text { staff in Akwa Ibom state civil Service. }\end{array}$ & $\begin{array}{c}189 \\
(33.15)\end{array}$ & $\begin{array}{c}301 \\
(52.80)\end{array}$ & $\begin{array}{c}53 \\
(9.29)\end{array}$ & $\begin{array}{c}27 \\
(4.73)\end{array}$ & 570 \\
\hline 2. & $\begin{array}{l}\text { Poor attitude to work contributes to worker's } \\
\text { lateness to offices in Akwa Ibom State civil } \\
\text { service. }\end{array}$ & $\begin{array}{c}251 \\
(44.04)\end{array}$ & $\begin{array}{c}261 \\
(45.79)\end{array}$ & $\begin{array}{c}36 \\
(6.32)\end{array}$ & $\begin{array}{c}22 \\
(3.86)\end{array}$ & 570 \\
\hline 3. & $\begin{array}{l}\text { Non motivational package in Akwa Ibom State } \\
\text { Civil Service negatively affect workers } \\
\text { commitment to assigned tasks }\end{array}$ & $228(40)$ & $\begin{array}{c}274 \\
(48.07)\end{array}$ & $\begin{array}{c}46 \\
(8.07)\end{array}$ & $\begin{array}{c}22 \\
(3.85)\end{array}$ & 570 \\
\hline
\end{tabular}

Table 3: Chi-square Calculation For hypothesis One

\begin{tabular}{|cccccc|}
\hline R-C & Fo & Fe & Fo-Fe & $(\mathbf{F o - F e})^{\mathbf{2}}$ & $\frac{\mathbf{( F o - F e}^{\mathbf{2}}}{\mathbf{F e}^{2}}$ \\
\hline $1-1$ & 189 & 222.67 & -133.67 & 1133.67 & 5.09 \\
$1-2$ & 301 & 278.67 & 22.22 & 498.62 & 1.79 \\
$1-3$ & 53 & 45.00 & 8 & 64 & 1.42 \\
$1-4$ & 27 & 23.67 & 3.33 & 11.10 & 0.46 \\
$2-1$ & 251 & 222.67 & 26.33 & 802.58 & 3.60 \\
$2-2$ & 261 & 278.67 & -17.67 & 312.22 & 1.12 \\
$2-3$ & 36 & 45.00 & -9 & 81 & 1.8 \\
$2-4$ & 22 & 23.67 & -1.67 & 2.78 & 0.11 \\
$3-1$ & 228 & 222.67 & 5.33 & 28.40 & 0.12 \\
$3-2$ & 274 & 278.67 & -4.67 & 21.80 & 0.07 \\
$3-3$ & 46 & 45.00 & 1 & 1 & 0.02 \\
$3-4$ & 22 & 23.67 & -1.67 & 2.78 & 0.11 \\
\hline Total & 1,710 & 1710.03 & 136.67 & 2959.95 & 15.71 \\
\hline
\end{tabular}

Source: (Author computation, 2021).

Table 4: Chi-square Computation for Research Hypothesis one.

\begin{tabular}{|cccccccc|}
\hline Questions & SA & A & SD & D & Total & $\mathbf{X}^{2}$ Cal. & $\mathbf{X}^{2}$ Tab. \\
1 & 189 & 301 & 53 & 27 & 570 & & \\
2 & 251 & 261 & 36 & 22 & 570 & & \\
3 & 228 & 274 & 46 & 22 & 570 & & 1 \\
Total & 668 & 836 & 135 & 71 & 1710 & 15.71 & 1 \\
\hline
\end{tabular}

Source: (Author Computation, 2021) 


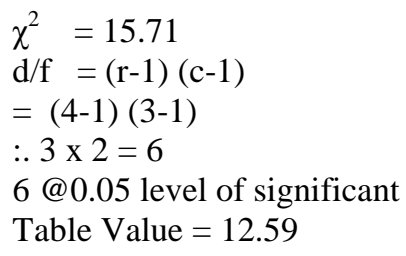

\section{Decision}

The above table shows that the computed $\left(\chi^{2}\right)$ value of 15.71 greater than the critical value of 12.592 in the statistical table at 0.05 level of significance. This implies that, the null hypothesis (Ho) is rejected and the alternative hypothesis (Hi) is accepted. This implies that lateness to work negatively affects organizational productivity in Akwa Ibom State civil service.

Table 5: Testing of Hypothesis ii: Responses on the research question ii: Lack of commitment ends to affect staff efficiency in Akwa Ibom State civil Service

\begin{tabular}{|c|c|c|c|c|c|c|}
\hline $\mathbf{S} / \mathbf{N}$ & Statements & SA & $\mathbf{A}$ & D & SD & Total \\
\hline 6. & $\begin{array}{l}\text { There is a significant relationship between } \\
\text { staff commitment and organizational } \\
\text { productivity in Akwa Ibom State civil } \\
\text { service }\end{array}$ & $\begin{array}{l}239 \\
(41.92)\end{array}$ & $\begin{array}{l}265 \\
(46.49)\end{array}$ & $48(8.42)$ & $\begin{array}{l}18 \\
(3.15)\end{array}$ & 570 \\
\hline 7. & $\begin{array}{l}\text { Lack of staff commitment as a result of } \\
\text { poor working environment affects } \\
\text { organizational productivity in Akwa Ibom } \\
\text { State civil service }\end{array}$ & $\begin{array}{l}186 \\
(32.63)\end{array}$ & $\begin{array}{l}207 \\
(36.31)\end{array}$ & $\begin{array}{l}93 \\
(16.31)\end{array}$ & $\begin{array}{l}84 \\
(14.73)\end{array}$ & 570 \\
\hline 8. & $\begin{array}{l}\text { Poor reward system adopted by Akwa Ibom } \\
\text { State government negatively affect workers } \\
\text { commitment to work in Akwa Ibom State }\end{array}$ & $\begin{array}{l}226 \\
(39.64)\end{array}$ & $\begin{array}{l}280 \\
(49.12)\end{array}$ & $36(6.31)$ & $\begin{array}{l}28 \\
(4.91)\end{array}$ & 570 \\
\hline
\end{tabular}

Source: Field Survey, 2021.

Table 6: Chi-square calculation for Hypothesis two

\begin{tabular}{|cccccc|}
\hline $\mathbf{1}$ & Fo & Fe & Fo-Fe & $(\text { Fo-Fe })^{\mathbf{2}}$ & $\frac{(\mathbf{F o - F e})^{\mathbf{2}}}{\text { Fe }}$ \\
\hline $6-1$ & 239 & 217 & 22 & 484 & 2.23 \\
$6-2$ & 265 & 250.66 & 14.34 & 205.63 & 0.82 \\
$6-3$ & 48 & 39 & 9 & 81 & 2.07 \\
$6-4$ & 18 & 43.33 & -25.33 & 641.60 & 14.80 \\
$7-1$ & 186 & 217 & -37 & 1369 & 6.30 \\
$7-2$ & 207 & 250.66 & -43.66 & 1906.19 & 7.60 \\
$7-3$ & 93 & 39 & 54 & 2916 & 74.76 \\
$7-4$ & 84 & 43.33 & 40.67 & 1654.04 & 38.17 \\
$8-1$ & 226 & 217 & 9 & 81 & 0.37 \\
$8-2$ & 280 & 250.66 & 29.34 & 860.83 & 3.43 \\
$8-3$ & 36 & 39 & -3 & 9 & 0.23 \\
$8-4$ & 28 & 43.33 & -15.33 & 235.00 & 5.42 \\
\hline Total & 1710 & 1709.97 & 304.67 & 9243.29 & 156.2 \\
\hline
\end{tabular}


Table 7: Chi-square Calculation for Hypothesis two

\begin{tabular}{|l|l|l|l|l|l|l|l|}
\hline & SA & A & SD & D & Total & $X^{2}$ Cal. & $X^{2}$ Tab. \\
\hline 6 & 239 & 265 & 48 & 18 & 570 & & \\
\hline 7 & 186 & 207 & 93 & 84 & 570 & & \\
\hline 8 & 226 & 280 & 36 & 28 & 570 & & 156.2 \\
\hline Total & 651 & 752 & 177 & 130 & 1710 & 1 \\
\hline
\end{tabular}

Source: Field Survey, 2021.

$\chi^{2}=156.2$

$\mathrm{d} / \mathrm{f}=(\mathrm{r}-1)(\mathrm{c}-1)$

$=(4-1)(3-1)$

:. $3 \times 2=6$ @ 0.05 level of significant

$\mathrm{Tv}=12.592$

\section{Decision}

The above table shows that the computed $\left(\chi^{2}\right)$ value of 156.2 is greater than the critical value of 12.592 in the statistical table at 0.05 level of significance. This implies that, the null hypothesis (Ho) is rejected in favour of the alternative hypothesis (Hi). This implies that lack of staff commitment negatively affects organizational efficiency in Akwa Ibom State civil service

\section{Result and Discussion of Findings}

This section deals with the analysis of the findings of the study. It is also intended to see how the $\chi^{2}$ decision relates to the statement of the problem. The study was carried out to examine the impact of organisational culture on workers' performance in Akwa Ibom State, using Akwa Ibom State civil service as a reference point. However, the two hypotheses formulated for the study were used for the calculation of the responses to the questionnaire. As could be evident from the calculation and analysis of the available data, all hypotheses rejected the null hypotheses in favour of the alternate hypotheses, which indicates the decision taken goes further to affirm that poor organisational culture affects workers' efficiency and productivity in the Akwa Ibom State civil service.

In testing hypothesis one, the study revealed that lateness to work negatively affects organisational productivity in Akwa Ibom State. Workers in the state civil service are addicted lateness in service delivery

and this has become part and parcel of their lifestyle. This is as a result of poor attitude to work and organizational culture which adversely affect their morale towards task accomplishment. As a result, workers should make every effort to report to their various posts of duty on time in order to complete their assigned tasks and duties on time.

The findings of hypothesis two reveal that lack of commitment among staff as a result of poor incentives and remuneration negatively affects workers' performance, which in turn leads to poor organisational productivity in the Akwa Ibom State civil service. Workers are not well paid, their salary and infringe benefits are not encouraging. Money that would have been used for the benefits of state bureaucrats are being diverted by politician for their selfish aggrandizement. Promotion and other entitlement are not given proper attention within the ministry. This in turn affect workers' productivity in Akwa Iboms Civil service. Accordingly, to improve staff commitment to work, the government should try all possible means of improving staff welfare and incentive packages in order to boost their morale for effective performance. Hence, civil service ethics on respecting senior officers should be strictly complied with to ensure efficiency and productivity in the Akwa Ibom State Civil Service. 


\section{Conclusion}

Culture is the total way of people's life. Organizational culture effects the way organisations operate. Workplace culture has an impact on organisational productivity as it affects workers' performance as a whole. Unlike any other public organization, the Nigerian Civil Service is bounded by culture and practices which regulate workers' behaviour and attitude towards work. The State civil service, which is supposed to be an instrument of effective service delivery, is faced with a performance malady and a dilemma that are largely due to the prevailing poor work culture and near absence of a performance management agenda. Consequently, morale is weak, efficiency is no more, competence has been ditched and merit abandoned due to non-adherence to the civil service culture and practices. The civil service still reels from politicization, merit sacrificed for quota-based recruitment/promotion, fraudulent staff claims, abuse of office/position, bribery and corruption, absenteeism, lateness, lack of organisational commitment or citizenship, idleness, insubordination, aggrandizement, etc. This in turn affects workers' performance as well as organisational productivity.

\section{Recommendations}

Based on the findings, the study recommends the following:

i. The Akwa Ibom State government should make it possible to improve workers' welfare and incentives. This, in turn, will boost employee morale and make them more committed to their assigned duties.

ii. The civil service ethics should be strictly adhered to by workers in order to be more productive and efficient in-service delivery. This will go a long way towards curtailing cases of corruption among civil servants.

iii. The government should place a mechanism on the ground to checkmate those inactive civil servants who only show up to sign the time book and later leave for their private businesses. Biometric machines should be placed to capture each staff member's biometric information as it relates to when they report to duty and when they close.

iv. Efficiency and productivity should be encouraged and valued, while late-comers and absenteeism should be seriously frowned upon.

\section{References}

Abada (eds) Readings on Comparative Public Administration Theory and Select Country Studies, Onitsha, Bookpoint Educational Ltd.

Afolabi O (2011). Public Service Rules, Financial Regulations and Guidelines on Public Procurement; Monetization Policy. Paper presented at a one-day Retreat of Honourable Ministers of Education with Directorate Staff, Heads of Parastatals Held at Abuja, 15th - 17th July, 2011.

Akpala, A. (1993). Management: An Introduction and Nigerian Perspective. Enugu: Precison Printers and Publishers.

Akpomouvire, M. (2007). The Ecology of Recruitment and Selection of Personnel in the Federal Civil Service of Nigeria. Journal of Humanities and Ecology171 (1)pp 18-32.

Anazodo, B. Okoye, Chukwuekeka, O. (2012).Public Administration in Nigeria: Nature, Principles and Application. Enugu: John Jacob’s Classic Publishers Ltd.

Anazodo, R. (2008). The Nigeria Civil Service in E. Obi, O. Obikeze L. Nwachuckwu and I,

Aniagoh Managing the Nigerian Worker (Lagos, Longman, 198), p. 195.

Armstrong, M. and Baron, B. (2012). Managing Staff Development and Productivity. London: Kogan Publishers.

Arowolo, D. (2012). Ethics, Motivation and Performance in Nigeria's Civil Service. Public Policy and Administration Research 2 (5)pp. 37-43. 
Aydogdu, J. and Asikgil, S. (2011). From New Public Management Strategies to Public Value: Paradigmatic Change and Managerial Implications. The Australia Journal of Public Administration, 16 (3)pp.353-366.

Baker, A. (2002). Organizational Culture, available at http://www.au.af.mil/au/awc/awcgate/doe/benchmark/ch11.pdf (Accessed June 2021)

Bernadin, O. (2010). Performance Management in Organizations. Toronto: Vantage Publishers.

Bhatia, R and Jain, V. (2012).Predictors of Organizational Commitment in India: Strategic

Boyle R and Donnell, O (2008) Understanding and Managing Organisational Culture, Committee for Public Management Research Discussion Paper 40, Dublin: Institute of Public Administration.

Brumbach, A. (2010). Staff Performance and Organizational Productivity. Accra: Kuffo Publishers.

Cameron K S and Quinn R E (2011) Diagnosing and Changing Organizational Culture: Based on the Competing Values Framework, John Wiley \& Sons.

Ejiofor P. (1984). “Making Our Organizations Perform”, Public Service Lectures Series, Anambra State Government, October, 1984

Ejionye, U. (1984). Industrial Relations of the 1980s and 1990s" in P.N.O. Ejiofor and V. A.

Ezeani, E. O. (2006). Fundamentals of Public Administration. Enugu: Snaap Press.

Federal Government of Nigeria. (2008). National Strategy for Civil Service Reform. Federal Government Printers, Abuja.

Human Resources Roles, Organizational Learning Capacity and Psychological Empowerment. Human Resource Management International Digest 15(3)pp.100-165

Idakwoji, P. (2011). Bureaucracy and Socio-economic Management in a Depressed Economy. Canadian Social Science 7(2), 244-248.

Imhonopi, D., and Urim,M. (2013). Leadership crisis and corruption in the Nigerian public sector: Analbatross of national development, The African Symposium, 13(1), 78- 87, June 2013.

Mathis, S. and Jackson, H. (2009). Managing People in the New Civil Service, Public Money and Management, 7,(1)pp. 19-33.

Michels, R. (1952). The Conservative Basis of Organization in R. Merton, A. Gray,B, Hockey and H. Selvin (eds) Reader in Bureaucracy, New York. The Free Press. (143-149).

Muchinsky, R (2003), The Politics of Service Delivery Reforms, Development and Change, Oxford, Blackwell publishing, Vol. 31(1).

Olaopa, T. (2010). Civil Service Reforms in Africa. Ibadan: Ibadan University Press Plc.

Schein, H. (2004). Organizational Culture and Leadership. San Francisco: Jossey-Brass

Selznick, P. (1952). A Theory of Organizational Commitment in R. Merton, A. Gray, B, Hockey and H. Selvin (eds) Reader in Bureaucracy, New York: The Free Press.

Suleiman, W. (2013). A study of causes of poor attitude to work among workers of both public and private sectors organizations in Bauchi State-Nigeria. International Journal of Academic Research in Business and Social Sciences, Vol. 3, No. 7.

Udokang, M. (2016). Foundations to the Study of Government and Politics, Uyo: Pressure Venture,pp 123134.

Wamakko, A. (2013). Introduction in Ethics and Discipline in Public Service (ed) Zaria: Ahmadu Bellow University Press Limited.

Weber, M. (1946). Bureaucracy: In H. Gerth and C. Wright Mils (eds) From Max Weber: Essays in Sociology: New York: Oxford University Press. 